NBER WORKING PAPER SERIES

\title{
SUING SOLELY TO EXTRACT \\ A SETTLEMENT OFFER
}

Lucian Arye Bebchuk

Working Paper No. 2161

NATIONAL BUREAU OF ECONOMIC RESEARCH

1050 Massachusetts Avenue

Cambridge, MA 02138

February 1987

I should like to thank Louis Kaplow and Steve Shavell for helpful comments on an earlier draft of this paper. Any opinions expressed are those of the author and not those of the National Bureau of Economic Research. 


\section{$\underline{\text { ABSTRACT }}$}

In many disputes, the expected value to the plaintiff from going to trial is negative, either because the chances of winning are small or because the litigation costs are large. While such a plaintiff would not go to trial, he might sue in the hope of extracting a settlement offer: the defendant might make such an offer if he is uncertain as to whether or not the expected value to the plaintiff of going to trial is negative. This paper seeks to identify the factors that determine: (i) whether a plaintiff who does not intend to go to trial will nonetheless succeed in extracting an offer; and (ii) how much will such a plaintiff succeed in extracting. 


\section{INTRODUCTION}

In many dispates, the potential plaintiff recognizes that the expected value to him of going to trial is negative. This might be the case either because the chances of winning a trial are small (the suit is "frivolons"') or becanse the expected judgment is small relative to the expected litigation costs. In such situations, however, the negative expected value of litigation might not deter the plaintiff from suing: the plaintiff might sue - hoping to extract a settlement offer from the defendant, and planning to drop the case if the defendant does not make such a settlement offer.

Suing solely to extract a settlement offer is rational, of conse, only if there is some likelihood that the plaintiff will receive such an offer. The question, then, is why a defendant would make a settlement offer to a plaintiff for whom the expected value of going to trial is negative. The answer to this question is not obvions: clearly, a plaintiff's threat of going to trial will not be credible if the defendant knows that it will not be in the plaintiff's interest to carry out the threat. 1

1. Thus, in examining this question, one should avoid assuming that defendants are influenced by threats that are not credible. Sach an assumption was nsed by $P^{\prime} n g(1983)$, who was first in seeking to mode1 how plaintiffs with negative-expected-value suits can extract a settlement offer. In his paper, a plaintiff with such a suit might sacceed in extracting an offer even though the defendant is assumed to know that the expected value of 1 itigation to the plaintiff is negative. The defendant might make such an offer because of his assumed belief that, if he does not make an offer, the plaintiff will go to trial. $P^{\prime} n g$ justifies this assumed belief on the grounds that it is never going to be contradicted by the facts; since the defendant's belief will lead to his making a settlement offer, the plaintiff's willingness to 1 itigate in the absence of such an offer will never be tested. But even 
This paper analyzes a main reason as to why plaintiffs with a negative-expected-value suit might nonetheless succeed in extracting a settlement offer. The explanation on which this paper focuses is one based on the presence of informational asymetry. The plaintiff might have some private information concerning the expected value to him of going to trial. For example, the plaintiff might have private information concerning the level of damages that he suffered as a result of the defendant's actions, or concerning his expected litigation costs

(including out-of-pocket expenses, the costs of the plaintiff's own time, the costs of the delay involved, and psychic costs). Consequently, a defendant might not know what the expected value of litigation to the plaintiff is, and thas also whether or not the plaintiff will go to trial if no settlement is reached. 2

though the defendant's assumed belief is not going to be contradicted by the facts, it is nonetheless an implausible belief. For, given $P^{\prime} \mathrm{ng}^{\prime} \mathrm{s}^{\prime}$ assumptions, the defendant knows that it will not be in the plaintiff's interest to go to trial, and there is thas no reason for the defendant to expect the plaintiff to do so in the absence of an offer. (In economic terminology, while P'ng was correct in proposing that the defendant's offering to settle belongs to the set of Nash equilibria, he should have raled out this outcome as one that does not belong to the set of perfect equilibria.)

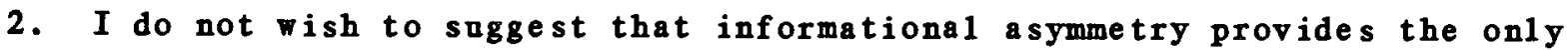
explanation as to why alaintiff with a negative-expected-value suit might succed in extracting a settlement offer. In particular, it is worth noting a different explanation that was recently offered by Rosenberg and Shave11 (1985). In their model, the defendant does know that the expected value of litigation to the plaintiff is negative and that consequently the plaintiff would not go to trial. What drives their results is their assumption about the sequential nature in which litigation costs are incurred. They assumed that, once a sait is filed (at no cost to the plaintiff), the defendant mast incur some significant costs to defend himself, otherwise the plaintiff wil win by defaut judgment and without incurring any litigation costs. The defendant knows that if he incars the necessary defense costs the plaintiff will drop the case. Yet, it is clearly rational for the defendant to pay anything below these defense costs in order to settle the case without having to incur these costs. Thes, in Rosenberg and Shavel1's mode1, suits are brought for their 'nuisance' value - the plaintiff's suit 
In the last few years, much attention has been devoted to developing formal models of settlement and litigation decisions under imperfect information (see, e.g., Bebchuk (1984), P'ng (1983), Reinganum and Wilde (1985), Salant (1984), and Samuelson (1983)). None of these models, however, has considered the important case in which the defendant is uncertain as to whether or not the expected value of litigation to the plaintiff is positive; to the extent that the defendant was assumed to face uncertainty, this assumed uncertainty was only about the size of a trial's value to the plaintiff but not about its sign. Thus, the literature has not analyzed how settlement decisions are affected by defendants' nncertainty as to whether the plaintiff will go to trial if a settlement is not offered.

This paper therefore develops a model of how, in the presence of such nncertainty, a defendant will decide whether to make a settlement offer, and, if so, how much to offer. On the one hand, the defendant will reason, the plaintiff might have a negative-expected-valne (NEV) suit, in which case offering to settle would be wasteful since the plaintiff would not go to trial anyway. On the other hand, the plain-

puts the defendant in a position in which he would have to incur some defense costs unless the plaintiff agrees to settle beforehand; and this makes the defendant willing to pay the plaintiff for such an agreement to settle.

While Rosenberg and Shavel1's explanation might well be relevant in some or many cases, it is unlikely to explain all the suits by plaintiffs who will not go to trial if the defendant refuses to settle. For in a great many cases the amonnt of defense costs that the defendant has to incur before the plaintiff incurs any litigation costs is very 1 imited. In such cases, a plaintiff that has a negative-present-value suit would be able to extact a significant settlement offer only if the defendant faces nncertainty concerning the expected value to the plaintiff of going to trial. 
tiff might have a positive-expected-value (PEV) suit, in which case making a settlement offer would possibly prevent 1 itigation and produce a beneficial settlement. The analysis identifies the factors that determine: (i) whether a plaintiff who does not intend to go to trial will nonetheless succed in extracting a settlement offer; and ( $i i)$ how much will such a plaintiff succed in extracting.

The analysis also identifies the effect that the presence of NEV suits has on the resolution of PEV suits. The fact that defendants take into account the possibility that the plaintiff's suit is a NEV one (and that the plaintiff will thus drop the case in the event that no settlement is reached) hurts those plaintiffs that do have a PEV suit. It is shown that the presence of NEV suits reduces the settlement amounts offered to plaintiffs with PEV suits and consequently increases the proportion of PEV suits that end up in a trial.

\section{THE MODEL}

\section{A. Sequence of Events}

A risk-neutral plaintiff files a suit against (or, more generally, makes a demand to) a risk-nentral defendant. Filing the suit (or making the demand) is assumed to be costless.

The subsequent sequence of events is as depicted in Figure 1 below. Following the suit, the defendant decides whether to offer to settle, and, if so, what settlement amonnt to offer. A decision to refrain from making a settlement offer will be referred to as a decision to offer a settlement amount 0 . 
Following the defendant's decision, the plaintiff decides how to respond. If the defendant offers some positive settlement amount, the plaintiff will have to decide whether to accept the offered settlement amount or go to trial. If the defendant does not offer to settle, the plaintiff will have to decide whether to drop the case (i.e., accept a settlement amount 0 ) or go to trial.

\section{B. The Consequences of a Trial}

The parties' decisions are made against the backgrond of a potential trial, which would involve litigation costs. The plaintiff estimates that, in the event of a trial, the expected judgment will be $W$ and his expected litigation costs will be $C_{p}$. Let $V=W-C_{p}$ denote the plaintiff's estimate of the expected value to him of going to trial. A plaintiff with an estimate $V$ will be referred to as one of type $V$.

The situation to be considered is one in which the plaintiff has some private information about $V$. It will be assumed at this stage that the plaintiff has private information only about $W$, and that the defendant knows $C_{p}$. The Appendix extends the analysis to the case where the plaintiff might have private information about both $W$ and $C_{p}$.

The defendant, then, does not know $v$, the plaintiff's type, but only the distribution from which $V$ is drawn. ${ }^{3}$ Specifically, the defen-

3. If the plaintiff is of a high type, then it will be in his interest to eliminate the informational asymetry and to have the defendant realize that the expected judgment is high. It will be assumed, however, that the plaintiff cannot el iminate the informational asymmetry in any way which is not prohibitively costly. A statement by the plaintiff about his high estimate of the expected judgment will be disregarded anless the plaintiff provides the defendant with verification of his high estimate. And the assumption is that the high-estimate plaintiff cannot provide such a verification, or that he cannot provide it without jeopardizing his chances should a trial take place. 
dant knows that $V$ is distributed with a density fanction $f($.$) and a$ cumalative distribution function $F($.$) . It is assumed that f($.$) is con-$ tinnons and differentiable thronghont, and that its value is positive in the interval $\left(-K_{1}, K_{2}\right)$, where $K_{1}, K_{2}>0$, and zero ontside this interval. Let as denote by a the 1 ikelihood that the plaintiff has a NEV suit: that is, $a=F(0)$. Also, let us denote by $g($.$) and G($.$) the$ density and cumalative distribation of $V$ conditional on $V \geq 0$. Thus, for any $x \geq 0$ we have

$$
\begin{aligned}
& f(x)=(1-a)_{g}(x) ; \text { and } \\
& F(x)=a+(1-a) G(x) .
\end{aligned}
$$

Finally, $C_{d}$ will denote the defendant's estimate of his expected litigation costs in the event of a trial. (The plaintiff might or might not know $c_{d^{*}}$ )

C. The Parties' Decisions

Consider first the plaintiff's decision whether to accept a settlement amount S. Clearly, the plaintiff will accept $S$ if and only if 4

(2) $S \geq V$

4. It is assumed for convenience that the plaintiff will settle if he is indifferent between settling and 1 itigating; the model's results will be the same nnder the opposite assumption. It is not saggested that informational asymmetry provides the only reason as to why plaintiff with a negative-expected-value suit might succeed in extracting a settlement offer. In particalar, it is worth noting a different explanation that was recently offered by 
Thus, the plaintiff will accept the offer if and only if his type is lower than S, the 'boorderline"' type. In particular, a settlement amount 0 will be accepted (i.e., a refusal to settle will lead to the plaintiff's dropping the case) if and only if the plaintiff's suit is a NEV one.

Turn now to the defendant's decision concerning which settlement amount $S$ to offer. The defendant knows that, if he offers an amount $S$, it will be accepted with a probability $F(S)$ and rejected with a probability 1-F(S). In the latter case, a trial will take place and the defendant's estimate of the expected judgment in such a trial is

$$
E(W / V>S)=E\left(V+C_{p} / V>S\right)=\int_{S}^{K_{2}}\left(x+C_{p}\right) f(x) d x
$$

Thus, the defendant's position if he offers a settlement amount $S$ wi11 be

$$
A(S)=-F(S) S-[1-F(S)]\left[C_{d}+\int_{S}^{K_{2}}\left(x+C_{p}\right) \frac{f(x)}{1-F(S)} d x\right]
$$

or, equivalently,

(4b)

$$
\begin{aligned}
A(S)= & -[a+(1-a) G(S)] S- \\
& -[1-a-(1-a) G(S)]\left[C_{d}+\int_{S}^{K^{2}}\left(x+C_{p}\right) \frac{f(x)}{1-a-(1-a) G(S)} d x\right]
\end{aligned}
$$

The defendant will choose $S$ to solve

$$
\max _{S} A(S)
$$


Differentiating (4a) with respect to $S$ and rearranging terms we get

(6a)

$$
A^{\prime}(S)=-F(S)+\left(C_{p}+C_{d}\right) f(S)
$$

or, equivalently,

$$
A^{\prime}(S)=-[a+(1-a) G(S)]+\left(C_{p}+C_{d}\right)(1-a)_{g}(S)
$$

The first term on the right-hand-side of $(6 a)$ or $(6 b)$ represents the marginal cost of increasing $S$ : there is a likelihood of $F(S)=a+$ (1-a)G(S) that the plaintiff wondd accept the increased offer and wonld have accepted it even without the increase.

The second term on the right-hand-side of $(6 a)$ or (6b) represents the marginal benefit of increasing $S$. Such an increase in $S$ would reduce the 1 ikelihood of litigation by $f(S)=(1-a) g(S)$. And observe that litigating against a plaintiff of the borderline type instead of settling with him involves a loss of $\left(C_{p}+C_{d}\right)$ to the defendant; for if the plaintiff is of the borderline type, the settlement amount will give the defendant all of the settlement gains $\left(C_{p}+C_{d}\right)$.

D. When wil1 a NEV Snit Stcceed?

Since a plaintiff with a NEV suit will in no case go to trial, a NEV suit will be successful if and only if $S^{*}>0$ - that is, if and only if the defendant elects to offer a positive settlement amount.

Proposition 1: (a) A necessary and sufficient condition for the defendant to offer a positive settlement amount is that there exists some $S>0$ for which

$$
[a+(1-a) G(S)] . S<(1-a) G(S)\left[C d+\int_{0}^{S}\left(x+C_{p}\right) \frac{g(x)}{G(S)} d x\right]
$$


(b) A sufficient condition for the defendant to offer a positive settlement amount is that

$$
a<\frac{\left(C_{p}+C_{d}\right) g(0)}{1+\left(C_{p}+C_{d}\right) g(0)} \text {. }
$$

Proof: (a) $S^{*}$ is positive if and only if there exists some $S>0$ for which $A(S)>A(0)$. Osing (4a) and rearranging terms gives (7).

(b) (8) implies that the value of $A^{\prime}(S)$ (see (4b)) is positive at $S=0.1 \mathrm{t}$ follows that (8) implies that $S^{*}>0$. Q.E.D.

Corollary 1: An increase in either $C_{p}$ or $C_{d}$ will make it more likely that the defendant will offer a positive settlement amount to the plaintiff.

Remark: An increase in either $C_{p}$ or $C_{d}$ increases (for any $S \geq 0$ ) the marginal benefit of increasing $S$ (see $(6 a)$ and ( $6 b)$ ). This is because the gain from settling with a plaintiff of the borderline type instead of litigating with him is equal to $\left(C_{p}+C_{d}\right)$.

Proof: An increase in either $C_{p}$ or $C_{d}$ increases the right-hand-side of (7) and does not affect the left-hand-side of (7). Therefore, such an increase makes it more 1 ikely that 17) will hold. Q.E.D.

Corollary 2: An increase in the 1ikelihood that the plaintiff's suit is a NEV one (i.e., an increase in a) will make it less likely that the defendant will offer a positive settlement amount. 
Remark: For any $S$, increasing a both raises the marginal cost of increasing $S$ and decreases the marginal benefit of increasing $S$ (see ( $6 a)$ and $(6 b))$. First, increasing a raises the marginal cost of increasing $S$ because it increases the likelihood that the plaintiff would accept the settlement offer even without the marginal increase in S. Second, increasing a lowers the marginal benefit of raising $S$ because it increases the extent to which this marginal increase in $S$ world lower the likelihood of litigation.

Proof: An increase in a will increase the left-hand-side of (7) and will decrease the right-hand side of (7). Therefore, such an increase will make it less likely that (7) will hold. Q.E.D.

E. How Mach wil1 a Successful NEV Snit Yield?

When (7) holds, a plaintiff who does not intend to go to trial. will nonetheless succed in extracting a positive settlement amount from the defendant. Let os now examine the factors that shape the size of that settlement amount.

Proposition 2: If the defendant elects to offer a positive settlement amont, that settlement amount will be characterized by

$$
\frac{g^{\prime}\left(S^{*}\right)}{g\left(S^{*}\right)}\left(C_{p}+C_{d}\right)<1
$$

Remark: Equation (9) is the first-order condition; it implies that at 
the defendant's optimal settlement offer the marginal cost and benefit of increasing the offer are equal. Equation (10) is the second-order condition.

Proof: In the situation under consideration, the optimal settlement offer $S *$ is interior to the interval $\left(0, K_{2}\right)$, becanse we assume that (7) holds and hence $S^{*}>0$, and because $A^{\prime}(S)(\sec (6 a))$ is negative at $K_{2}$. Consequently, at $S$ * the first-order and second-order conditions must hold. Requiring that $A^{\prime}(S)$ be equal to zero at S* gives (9). Differentiating $A^{\prime}(S)$ with respect to $S$, rearranging terms, and requiring negativity at $S *$ gives (10). Q.E.D.

Corollary 1: An increase in either $C_{p}$ or $C_{d}$ will raise the amount that a successul NEV suit will yield.

Remark: As already explained, an increase in either $C_{p}$ or $C_{d}$ will raise the marginal benefit of increasing $S$.

Proof: Differentiating (9) with respect to $\left(c_{p}+c_{d}\right)$ and rearranging terms gives

$$
\frac{\partial S^{*}}{\partial\left(C_{p}+C_{d}\right)}=\frac{1}{1-\left(C_{p}+C_{d}\right) \frac{g^{\prime}\left(S^{*}\right)}{g\left(S^{*}\right)}}
$$

And the second-order condition (10) implies that the right-hand side of (11) is positive. Q.E.D.

Corollary 2: An increase in the likelihood that the plaintiff's suit is a NEV one (an increase in $\alpha$ ) will reduce the amount that a successul NEV suit will yield. 
Remark: As already explained, increasing a will both raise the marginal cost of increasing $S$ and lower the marginal benefit of increasing $S$.

Proof: Differentiating (9) with respect to a and rearranging terms gives

$$
\frac{\partial S^{*}}{\partial a}=-\frac{\left(C_{p}+C_{d}\right)+\left(1-G\left(S^{*}\right)\right)}{\left.(1-a)\left[1-C_{p}+C_{d}\right) \frac{g^{\prime}\left(S^{*}\right)}{g\left(S^{*}\right)}\right]} .
$$

And the second-order condition (10) implies that the right-hand side of (12) is negative. Q.E.D.

F. The Effect of NEV Snits on the Resolution of PEV Suits

Let us now turn to the effect that the presence of NEV suits has on the resolution of PEV saits.

Proposition 3: In comparison to the situation that would obtain if there were no NEV suits, the presence of NEV suits (a) lowers the settlement amounts for which PEV are settled; and (b) increases the proportion of PEV suits that are not settled but rather lead to trial.

Remark: The intuition behind the two parts of the Proposition is as follows. (a) As is clear from the remark explaining Corollary 2 of Proposition 2, the possibility that the suit is a NEV one leads defendants to offer lower settlement amounts than they would otherwise offer.

(b) Because the presence of NEV suits lowers the settlement amounts offered by defendants, it increases the likelihood that a plaintiff with a PEV suit will reject the offer made to him and go to trial. 
Proof: (a) Proposition 1(b) and Corollary 2 of Proposition 2 indicate that $S^{*}$ is 10 wer than what it woold be if a were equal to 0 - that is, if there were no likelihood that the plaintiff's suit is a NEV one.

(b) The likelihood that a PEV suit will lead to trial is 1$G\left(S^{*}\right)$, which obviously increases as $S^{*}$ is lowered.

\section{CONCLUDING REMARKS}

1. The analysis of this paper suggests a main way in which legal roles and institutions affect the incidence and success of suits solely aimed at extracting a settlement of fer. As was shown, the possibility of bringing a successfal NEV suit is facilitated by the presence of informational asymmetry concerning the value to the plaintiff of going to trial. Various legal roles and institutions affect, of course, the extent to which such an informational asymmetry might be present. For example, discovery roles often enable the defendant to learn some of the plaintiff's private information concerning the expected outcome of a trial. Rales and institations which reduce such informational asymmetries are likely to make it more difficult for NEV suits to be successful (and thas also to increase the proportion of PEV suits that will be settled).

2. An important issue of interest that the model leaves aneramined is that of information transmission. The model's assumption that the defendant is the only party that makes settlement offers is used to role out the possibility of defendants' learning from plaintiffs' demands: 
if the plaintiff were to make a settlement demand, the defendant might infer from it some information concerning the plaintiff's type, and the informational asymmetry might be consequently reduced. This possibility of information transmission through plaintiff' demands is an issue that should be treated in a complete model of suits by plaintiffs who will not go to trial if the defendant does not settle. 


\section{APPENDIX}

This Appendix extends the analysis to the case where the plaintiff might have private information not only about What also about $\mathrm{C}_{\mathrm{p}}$.

Consider, under the new assumption, the defendant's choice of $S$. The defendant knows that an offer $S$ will be accepted with a probability $F(S)$ and rejected with a probability $1-F(S)$. In the 1atter case, a trial will take place and the defendant's estimate of the expected judgment in such a trial is

$$
\begin{aligned}
& E(W / V>S)=E\left(V+C_{p} / V>S\right)= \\
& E(V / V>S)+E\left(C_{p} / v>S\right)= \\
& \int_{S}^{K_{2}} \frac{f(x)}{1-F(S)} d x+\int_{S}^{K_{2}} E\left(C_{p} / V=x\right) \frac{f(x)}{1-F(S)} d x .
\end{aligned}
$$

Thus, the defendant's expected position if he offers a settlement amount $S$ will be

$$
A(S)=-F(S) S-[1-F(S)]\left[C_{d}+\int_{S}^{K_{2}} E\left(C_{p} / V=x\right) \frac{f(x)}{1-F(S)} d x+\int_{S}^{K_{2}} x \frac{f(x)}{1-F(S)} d x\right],
$$

or, equivalently,

$$
\begin{aligned}
A(S)= & -[a+(1-a) G(S)] . S- \\
& -[1-a-(1-a) G(S)]\left[C_{d}+\int_{S}^{K_{2}} E\left(C_{p} / V=x\right) \frac{f(x)}{1-F(S)} d x+\int_{S}^{K_{2}} x \frac{f(x)}{1-F(S)} d x\right] .
\end{aligned}
$$

The defendant will of course choose $S$ to maximize the value of $A(S)$. Differentiating the right-hand side of (A2) with respect to $S$ gives 


$$
A^{\prime}(S)=-F(S)+f(S)\left[C_{d}+E\left(C_{p} / V=S\right)\right]
$$

or, equivalently,

$$
A^{\prime}(S)=-[a+(1-a) G(S)]+(1-a) g(S)\left[C_{d}+E\left(C_{p} / V=S\right)\right]
$$

The interpretation of (A4) and (A5) is similar to that of (6a) and (6b). The first term on the right-hand side of (A4) or (A5) represents the marginal cost of increasing $S$ : there is a likelihood of $F(S)=a+$ (1-a)G(S) that the plaintiff would accept the increased offer and would have accepted the offer even without the marginal increase. The second term on the right-hand side of (A4) or (A5) represents the marginal benefit of increasing $S$. Such an increase in $S$ would reduce the 1 ike1ihood of 1 itigation by $f(S)=(1-a)_{g}(S)$; and 1 itigating against a plaintiff of the borderline type instead of settling with him would involve loss of $\left[C_{d}+E\left(C_{p} / V=S\right)\right]$.

Proceeding in a similar way to that followed in Section II, the following propositions and corollaries can be proved.

Proposition Al: (a) A necessary and sufficient condition for the defendant to offer a positive settlement amonnt is that there exists some $S>0$ for which

$$
[a+(1-a) G(S)] . S<(1-a) G(S)\left\{C_{d}+\int_{0}^{S}\left[E\left(C_{p} / V=x\right)+x\right] \frac{g(x)}{G(S)} d x\right]
$$

(b) A sufficient condition for the defendant to offer a positive settlement amount is that 
(A7)

$a<\frac{\left[C_{d}+E\left(C_{p} / V=0\right)\right]_{g}(0)}{1+\left[C_{d}+E\left(C_{p} / V=0\right)\right]}$

Corollary 1: An increase in $C_{d}$ will make it more likely that the defendant will offer a positive settlement amount, Similarly, an upward shift in the distribation of $C_{p}$ (holding fixed the distribation of V) will make it more likely that the defendant will offer a positive settlement amornt.

Corollary 2: An increase in the likelihood that the plaintiff's suit is a NEV one (an increase in a) will make it less likely that the defendant will offer a positive settlement amount.

Proposition A2: If the defendant elects to offer a positive settlement amount, that settlement amount will be characterized by

$$
\begin{aligned}
& a+(1-\alpha) G\left(S^{*}\right)=(1-\alpha) g\left(S^{*}\right)\left[C_{d}+E\left(C_{p} / V=S^{*}\right)\right] ; \text { and } \\
& \frac{g^{\prime}\left(S^{*}\right)}{g\left(S^{*}\right)}\left[C_{d}+E\left(C_{p} / V=S^{*}\right)\right]<1
\end{aligned}
$$

Corollary 1: An increase in $C_{d}$ will raise the settlement amount that a saccessfal NEV suit will yield. Similarly, an apwards shift in the distribation of $C_{p}$ (holding fixed the distribation of $V$ ) will increase the settlement amount that a successful NEV suit will yield. 
Corollary 2: An increase in the likelihood that the plaintiff's suit is a NEV one (an increase in a) will reduce the amount that a successful NEV suit will yield.

Proposition 3: In comparison to the situation that would obtain if there were no NEV suits, the presence of NEV suits (a) lowers the settlement amounts for which PEV are settled; and (b) increases the proportion of PEV saits that are not settled but rather lead to trial. 


\section{REFERENCES}

Bebchak, L. (1984). 'Litigation and Settlement under Imperfect Information.' 18 Rand Journal of Economics, pp. 404-415.

P'ng, 1. (1983). ''Strategic Behavior in Suit, Settlement, and Tria1."' 14 Bell Journal of Economics, pp. 839-550.

Reinganum, J. and L. Wilde (1985). 'Settlement, Litigation and the Allocation of Litigation Costs.' ' Division of Humanities and Social Sciences, California Institute of Technology, March.

Rosenberg, D. and S. Shave11 (1985). "A Model in Which Saits Are Brought for Their Nuisance Value." 5 International Review of Law and Economics, pp. 3-13.

Salant, S. (1984). "Litigation of Settlement Demands Qnestioned by Bayesian Defendants." Social Science Working Paper No. 816, Division of Hamanities and Social Sciences, California Institute of Technology, March.

Samuelson, W. (1983). "Negotiation vs. Litigation." School of Management, Boston University, April. 